University of Nebraska - Lincoln

DigitalCommons@University of Nebraska - Lincoln

Faculty Publications from the Harold W. Manter Laboratory of Parasitology

6-1989

\title{
Coccidian Parasites (Apicomplexa: Eimeriidae) from Two Species of Caimans, Caiman yacare Daudin and Caiman latirostris Daudin (Alligatoridae), from Paraguay
}

\author{
Aida Luz Aquino-Shuster \\ Ciudad Universitaria, San Lorenzo \\ Donald W. Duszynski \\ University of New Mexico, eimeria@unm.edu
}

Follow this and additional works at: https://digitalcommons.unl.edu/parasitologyfacpubs

Part of the Parasitology Commons

Aquino-Shuster, Aida Luz and Duszynski, Donald W., "Coccidian Parasites (Apicomplexa: Eimeriidae) from Two Species of Caimans, Caiman yacare Daudin and Caiman latirostris Daudin (Alligatoridae), from Paraguay" (1989). Faculty Publications from the Harold W. Manter Laboratory of Parasitology. 166. https://digitalcommons.unl.edu/parasitologyfacpubs/166

This Article is brought to you for free and open access by the Parasitology, Harold W. Manter Laboratory of at DigitalCommons@University of Nebraska - Lincoln. It has been accepted for inclusion in Faculty Publications from the Harold W. Manter Laboratory of Parasitology by an authorized administrator of DigitalCommons@University of Nebraska - Lincoln. 


\title{
COCCIDIAN PARASITES (APICOMPLEXA: EIMERIIDAE) FROM TWO SPECIES OF CAIMANS, CAIMAN YACARE DAUDIN AND CAIMAN LATIROSTRIS DAUDIN (ALLIGATORIDAE), FROM PARAGUAY
}

\author{
Aida Luz Aquino-Shuster* and Donald W. Duszynski \\ Department of Biology, The University of New Mexico, Albuquerque, New Mexico 87131
}

\begin{abstract}
From October 1986 to January 1987, feces from 119 Caiman yacare and 12 Caiman latirostris were collected in Paraguay and later examined for coccidian oocysts; 69 of 119 (58\%) samples from $C$. yacare and 3 of $12(25 \%)$ samples from $C$. latirostris contained coccidian oocysts. Two eimerians infected $C$. yacare and both are described as new species. Sporulated oocysts of Eimeria paraguayensis n. sp. are ellipsoid, 34.0 $\times 23.6(26-38 \times 20-29) \mu \mathrm{m}$ with sporocysts ovoid, $14.0 \times 7.1(10-19 \times 6-10) \mu \mathrm{m}$. Sporulated oocysts of Eimeria caimani $\mathrm{n}$. sp. are spheroid, 22.4 (19-29) $\mu \mathrm{m}$ with sporocysts ovoidal, $12.9 \times 6.5(8-17 \times 5-8) \mu \mathrm{m}$. Isospora jacarei infected $C$. latirostris and is redescribed. Sporulated oocysts of $I$. jacarei are sub-spheroid, 13.2 $\times 12.1(10-18 \times 10-15) \mu \mathrm{m}$ with sporocysts ellipsoid, $10.4 \times 5.8(7-13 \times 4-11) \mu \mathrm{m}$. To date, members of the Eimeriidae found in Crocodylia include 5 species of Eimeria and 2 of Isospora including the new species described here.
\end{abstract}

From October 1986 to January 1987 , a group of biologists from the University of New Mexico had the opportunity to work throughout Paraguay surveying many aspects of caiman biology, systematics, and population status. One part of that study was to determine the species and distribution of coccidian parasites of caimans in Paraguay. This paper reports our findings.

\section{MATERIALS AND METHODS}

Caimans were collected from 11 localities in Paraguay (Fig. 1). All were captured alive and fecal samples collected and placed in $2 \%(\mathrm{w} / \mathrm{v})$ aqueous potassium dichromate $\left(\mathrm{K}_{2} \mathrm{Cr}_{2} \mathrm{O}_{7}\right)$ solution. After returning from South America, samples were processed by filtering the fecal suspension through 60-mesh wire screens and then incubating the material at room temperature (ca. 23 C) for 2 wk in covered petri dishes. Following the methods of Duszynski et al. (1982) the material was examined for oocysts. Oocysts were measured and photographed with a Zeiss universal photomicroscope equipped with both Neofluar and Nomarski-interference $100 \times$ objective lenses. All measurements are in $\mu \mathrm{m}$ with ranges of measurements in parentheses following the means. Oocysts were measured when they were 535 days old or younger.

\section{RESULTS}

Coccidian species found, hosts, and host localities are presented in Table I and Figure 1.

Received 25 October 1988; revised 7 February 1989 ; accepted 7 February 1989.

* Present address: Inventario Biológico Nacional, Museo de Historia Natural de Paraguay, Ministerio de Agricultura y Ganadería, Sucursal 19, Ciudad Universitaria, San Lorenzo, Paraguay.
Sixty-nine of $119(58 \%)$ Caiman yacare and 3 of 12 (25\%) Caiman latirostris were passing coccidian oocysts. All infected C. yacare discharged only eimerian oocysts representing 2 species, whereas the infected C. latirostris discharged only isosporan oocysts. Two species of Eimeria are described here as new species and the isosporan redescribed.

\section{Eimeria paraguayensis n. sp.} (Figs. 2-4, 11)

\section{Description}

Oocyst ellipsoid, wall $\sim 1.0$, composed of 2 layers of equal thickness: outer layer pitted (Fig. 4), pale yellow to colorless, inner layer smooth; micropyle absent; 1 highly refractile polar body sometimes present (Fig. 2); oocyst residuum composed of tiny granules that form a diffuse, irregular mass $\leq 15$ in diameter (Fig. 3); sporulated oocysts $(n=55) 34.0 \times 23.6(26-38 \times 20-29)$ with length/width $(\mathrm{L} / \mathrm{W})$ ratio $1.4(1.1-1.7)$; sporocysts $(\mathrm{n}=55)$ ovoid, $14.0 \times 7.1(10-19 \times 6-10)$ with $\mathrm{L} / \mathrm{W}$ ratio 1.9 (1.5-2.4); Stieda body present at pointed end of sporocyst (Fig. 2), sub- and parastieda bodies absent; sporocyst residuum (Figs. 2, 4) of highly refractile granules in a compact mass $(\sim 6-8)$; sporozoites with 2 large refractile bodies that are usually spheroid $(\sim 4)$ and located in the middle and posterior of each sporozoite.

\section{Taxonomic summary}

Type host: Caiman yacare Daudin, 1802, Florida State Museum, Herpetology Section, Aquino-Scott C18, 12 October 1986.

Type locality: Laguna Vicente, $1 \mathrm{~km} \mathrm{~W}$ headquarter Estancia Juan de Zalazar, Departamento Presidente Hayes, Paraguay.

Prevalence: Found in 51 of 119 (43\%) C. yacare.

Site of infection: Unknown, oocysts recovered from feces.

Material deposited: Syntypes (=phototypes, see 


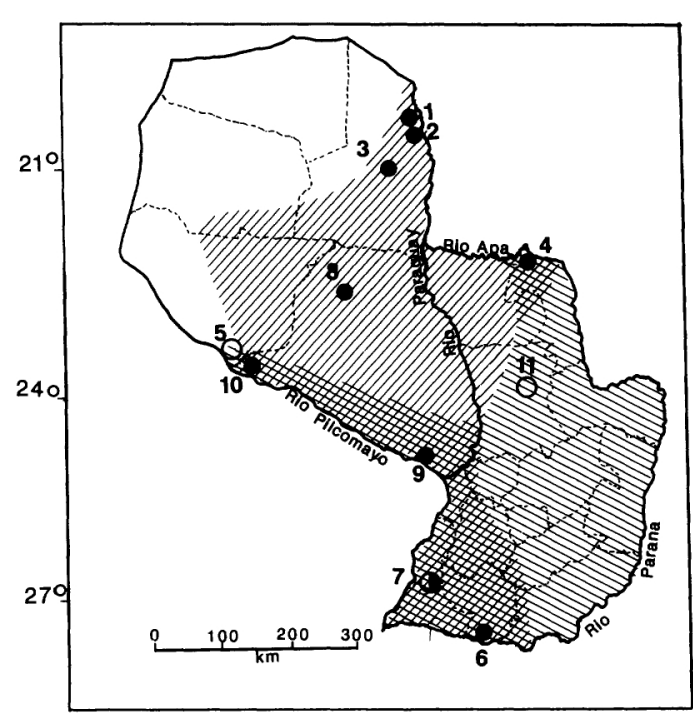

Figure 1. Map of Paraguay, South America, showing its 20 departments (states). Shaded areas show the distributions of Caiman latirostris $(\mathbb{W})$ and Caiman yacare ( Solid circles (O) show localities where $C$. yacare was collected, open circles $(O)$ where $C$. latirostris was collected, and half open circles $(\boldsymbol{O})$ where both species were collected.

Bandoni and Duszynski, 1988) of sporulated oocysts, U.S. National Museum Parasite Collection (USNMPC) No. 80580 .

Etymology: The nomen triviale combines the name of the country from which infected hosts were taken and -ensis ( $\mathrm{L}$., belonging to).

\section{Remarks}

Three other eimerians have been described from reptiles in the order Crocodylia (Simond, 1901; Carini, 1932; Lainson, 1968; Levine, 1988), but only Eimeria pintoi Carini, 1932, an ellipsoid form, remotely resembles E. paraguayensis. Unfortunately, Carini's description (1932) is incomplete; he described oocysts of $E$. pinto $i$ to be $33 \times 22$ and sporocysts to be $11 \times 8$, but he made no mention of a pitted wall, a polar granule, or a sporocyst residuum and he described the oocyst as ovoidal. Carini examined just 1 small "caiman" of an unknown species.

\section{Eimeria caimani n. sp.}

(Figs. 5-7, 12)

\section{Description}

Oocyst spheroid, wall $\sim 1.0$ consisting of 2 layers of equal thickness: outer layer pitted (Fig. 7), inner layer smooth; micropyle and polar body absent; oocyst residuum compact, spheroid mass (Fig. 5) of small refractile granules, $\sim 9-10$; sporulated oocysts $(n=50)$ $22.4(19-29)$; sporocysts $(n=50)$ ovoid, $12.9 \times 6.5$ (8-17 x 5-8) with L/W ratio 1.9 (1.2-2.1); Stieda body at slightly pointed end of sporocyst (Fig. 5), sub- and parastieda bodies absent; sporocyst residuum compact, irregular mass of highly refractile granules (Figs. 5, 6), $\sim 6$ wide; sporozoites with 1 round refractile body near posterior end, but not always terminal.

\section{Taxonomic summary}

Type host: Caiman yacare Daudin, 1802, Florida State Museum, Herpetology Section, Aquino-Scott C37, 31 October 1986.

Type locality: Retiro Pozo Arias on Rio Monte Lindo, $18 \mathrm{~km}$ S Fortin Avalos Sanchez, Estancia Tinfunque, Departamento Presidente Hayes, Paraguay.

TABLE I. Coccidians collected from Caiman latirostris and Caiman yacare from 11 localities in Paraguay, South America.

\begin{tabular}{|c|c|c|}
\hline Location & $\begin{array}{c}\text { Number infected/' } \\
\text { number examined (\%) }\end{array}$ & Eimeria/Isospora spp. \\
\hline \multicolumn{3}{|l|}{ Alto Paraguay } \\
\hline$(1)^{*}$ Estancia Dona Julia & $9 / 21(43)$ & E. paraguayensis, E. caimani \\
\hline (2) Estancia P. Ramos & $12 / 24(50)$ & E. paraguayensis, E. caimani \\
\hline (3) Estancia Gral. Diaz & $11 / 15(73)$ & E. paraguayensis, E. caimani \\
\hline \multicolumn{3}{|l|}{ Amambay } \\
\hline (4) near Bella Vista & $2 / 3 \quad(67)$ & E. paraguayensis, E. caimani \\
\hline \multicolumn{3}{|l|}{ Boqueron } \\
\hline (5) Estancia Tinfunque & $3 / 10(30)$ & I. jacarei \\
\hline \multicolumn{3}{|l|}{ Misiones } \\
\hline (6) Estancia Sarandy & $3 / 8 \quad(38)$ & E. paraguayensis, E. caimani \\
\hline \multicolumn{3}{|l|}{ Ñeembucu } \\
\hline (7) Estancia 26 & $8 / 10(80)$ & E. paraguayensis, E. caimani \\
\hline \multicolumn{3}{|l|}{ Presidente Hayes } \\
\hline (8) Estancia J. de Zalazar & $8 / 15(53)$ & E. paraguayensis, E. caimani \\
\hline (9) Estancia La Golondrina & $4 / 8 \quad(50)$ & E. paraguayensis, E. caimani \\
\hline (10) Estancia Tinfunque & $11 / 16(69)$ & E. paraguayensis, E. caimani \\
\hline \multicolumn{3}{|l|}{ San Pedro } \\
\hline (11) Estancia Santa Maria & $0 / 1 \quad(0)$ & - \\
\hline
\end{tabular}

\footnotetext{
* Map locality, Figure 1.
} 


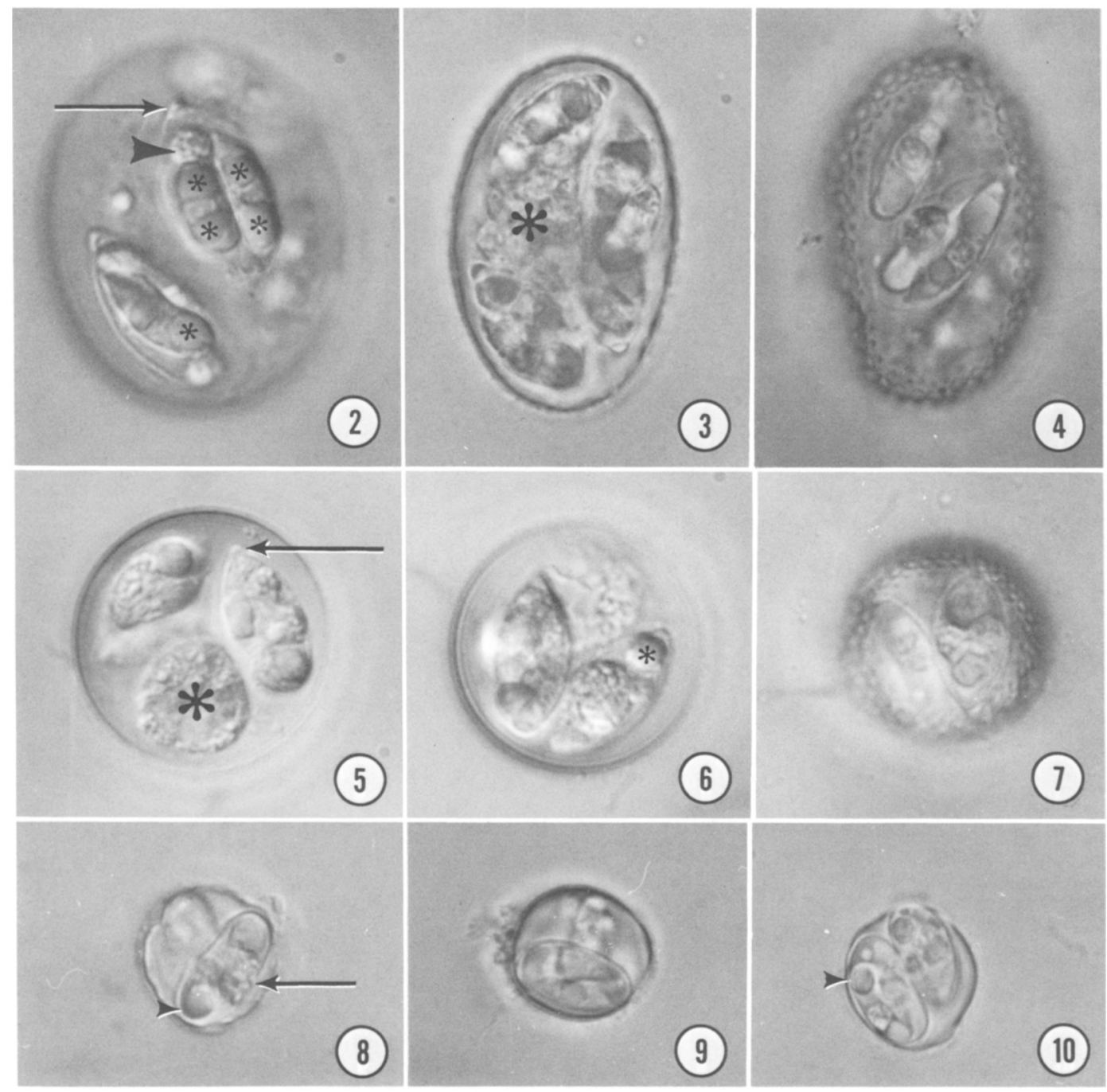

FIGURES 2-10. Photomicrographs of sporulated oocysts of coccidia found in caimans collected in Paraguay. $\times$ 1,860. 2-4. Eimeria paraguayensis $\mathrm{n}$. sp. 2. Note Stieda body (arrow), sporocyst residuum (large arrowhead), and sporozoite refractile bodies $(*)$. 3. Oocyst residuum $\left({ }^{*}\right)$ that sometimes embeds the sporocysts. 4. Pitted outer oocyst wall. 5-7. Eimeria caimani n. sp. 5. Note large oocyst residuum $\left({ }^{*}\right)$ and Stieda body (arrow). 6. Sporozoite refractile body (*). 7. Pitted outer oocyst wall. 8-10. Isospora jacarei. Note sporocyst residuum (arrow), sporozoite refractile bodies (arrowheads), lack of a Stieda body on sporocysts, and small size of oocysts compared to the 2 eimerians.

Prevalence: Found in 56 of $119(47 \%)$ C. yacare. Site of infection: Unknown, oocysts recovered from feces.

Material deposited: Syntypes (=phototypes, see Bandoni and Duszynski, 1988) of sporulated oocysts, USNMPC No. 80579.

Etymology: The nomen triviale is derived from the generic name of the host.

\section{Remarks}

The other 2 eimerians described from Crocodylia have spheroid/subspheroid oocysts (Eimeria crocodyli Lainson, 1968, from Crocodylus acutus and Eimeria kermoganti [Simond, 1901] Braun, 1908, from Gavialis gangeticus), but they both lack an oocyst residuum and Stieda bodies. Thus, sporulated oocysts of $E$. caimani do not resemble those from the other eimerians described to date from Crocodylia.

\section{Isospora jacarei Carini and Biocca, 1940} (Figs. 8-10)

\section{Description}

Oocyst subspheroid to spheroid; wall $\ll 1$, composed of 2 smooth layers of equal thickness; micropyle, oocyst residuum, and polar body absent; sporulated oocysts 


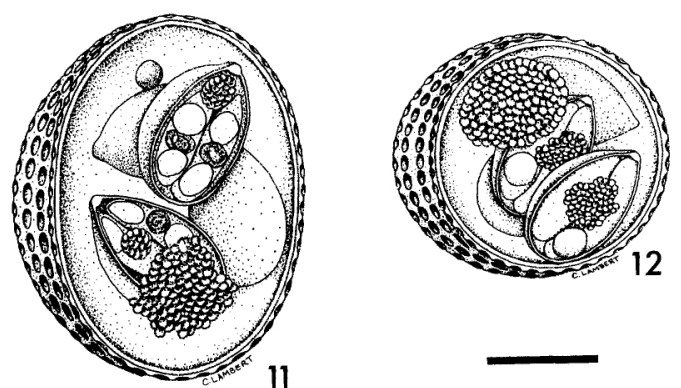

Figures 11, 12. Line drawings show suggested morphology of sporulated oocysts of coccidia collected from the feces of Caiman yacare; bar $=10 \mu \mathrm{m} .11$. Eimeria paraguayensis n. sp. 12. Eimeria caimani n. sp.

(n = 73) $13.2 \times 12.1(10-18 \times 10-15)$ with $\mathrm{L} / \mathrm{W}$ ratio $1.1(1.0-1.5)$; sporocysts $(n=73)$ ellipsoid, $10.4 \times 5.8$ $(7-13 \times 4-11)$ with $\mathrm{L} / \mathrm{W}$ ratio $1.7(1.1-2.2)$; Stieda body, sub-, and parastieda bodies absent; sporocyst residuum a small compact mass of granules (Figs. 8, 10 ); sporozoites with 1 round refractile body near posterior end (Fig. 9).

\section{Taxonomic summary}

Locality: Retiro Alonsito, $8.5 \mathrm{~km}$ NW Fortin Avalos Sanchez, Estancia Tinfunque, Departamento Boquerón, Paraguay.

Prevalence: Found in 3 of 12 (25\%) C. latirostris.

Site of infection: Unknown, oocysts recovered from feces.

\section{Remarks}

The oocysts we describe here are nearly identical to those described by Carini and Biocca (1940) from $C$. latirostris from Brazil. The only significant difference was that we found considerable variation in oocyst shape due to the flexible thin wall that was not mentioned by Carini and Biocca. We also provide photomicrographs of sporulated oocysts that the original description lacked. There is 1 other Isospora described from a Crocodylia, Isospora wilkiei Lainson, 1968, from Crocodilus acutus, but the oocysts of this species are ellipsoid and larger than the form we describe here.

\section{DISCUSSION}

Caiman species are distributed from southern Mexico to northern Argentina (Medem, 1983). The genus may include as many as $\mathbf{3}$ species, but the exact number of species has not yet been resolved (Scott et al., 1989). Caiman yacare is distributed in Argentina, Bolivia, Brazil, and Paraguay (Aquino-Ortiz, 1988) where they inhabit permanent waters of large rivers and swamps (Scott et al., 1989). Caiman latirostris is distributed in northern Argentina, southern Brazil, Paraguay, and Uruguay (Medem, 1983) being sympatric to $C$. yacare in some parts of its distribution, including in Paraguay (Fig. 1). The habitat of $C$. latirostris is ephemeral, such as stock tanks and seasonal swamps, and this species is more aggressive in colonizing new sources of water than is C. yacare (Scott et al., 1989).

In Paraguay, $C$. yacare is still abundant in the lower Chaco especially in regions where hunting is prohibited. However, $C$. latirostris has suffered a high degree of exploitation for hides and its population has declined considerably in recent years.

In this paper we have described 2 new species of Eimeria and redescribed 1 Isospora sp. It is curious that $C$. yacare was infected only with eimerian species and $C$. latirostris only by $I$. jacarei, even though there is considerable overlap in habitat between the 2 host species; we have no explanation for this difference. Forty-four of the $69(64 \%)$ infected $C$. yacare had both species of Eimeria when examined, whereas 13 of 69 (19\%) had oocysts of only E. caimani and 8 of $69(12 \%)$ had oocysts of only E. paraguayensis.

Prior to this study, only 5 species of Eimeriidae from 3 species of Crocodylia had been described, but the descriptions of most of these were rather incomplete and some of the analyses were done with very few host samples. Therefore, phylogeny of hosts and parasites and coevolutionary relationships that may exist are unknown at present.

\section{ACKNOWLEDGMENTS}

We are indebted to Dr. Norman J. Scott, Jr., Mr. Carl Shuster, and Mr. Lee Fitzgerald, The University of New Mexico, and to Nora Neris, National Museum of Paraguay, for help in collecting caimans. We also thank Ms. Paulette Ford for general assistance, Ms. Christine Lambert for the line drawings, and Dean Marcus Price, Office of Graduate Studies, University of New Mexico, for financial support of this work. This research was made possible by a grant from the Convention on International Trade in Endangered Species of Wild Fauna and Flora (CITES).

\section{LITERATURE CITED}

AQuino-OrTIZ, A. L. 1988. Ontogenetic food shifts and their relation to morphological changes in the crocodilian Caiman yacare. M.S. Thesis. University of New Mexico, Albuquerque, $77 \mathrm{p}$.

BANDONI, S. M., AND D. W. DusZYNSKI. 1988. A plea for improved presentation of type material for coccidia. Journal of Parasitology 74: 519-523.

CARIN, A. 1932. Eimeria pintoi n. sp. parasita de um jacaré. Sociedad Argentina de Patologia Regional del Norte 2: 922-923. 
- AND E. BIOCCA. 1940. Uma nova Isospora do intestino do jacaré. Arquivos de Biologia 24: 252-253.

Duszynski, D. W., G. Eastham, and T. L. Yates. 1982. Eimeria from jumping mice (Zapus spp.): A new species and genetic and geographic features of Z. hudsonicus luteus. Journal of Parasitology 68: $1146-1148$.

LAINSON, R. 1968. Parasitological studies in British Honduras. IV: Some coccidial parasites of reptiles. Annals of Tropical Medicine and Parasitology 62: 260-266.

LEVINE, N. D. 1988. The protozoan phylum Apicom- plexa, Vol. I. CRC Press, Inc., Boca Raton, Florida, $203 \mathrm{p}$.

Medem, F. 1983. Los Crocodylia de Sur America, Vol. II. National Ministry of Education, Bogota, Colombia, $270 \mathrm{p}$.

Scott, N. J., JR., A. L. Aquino, And L. A. Fitzgerald. 1989. Distribution, habitats, and conservation of the caimans (Alligatoridae) of Paraguay. Vida Silvestre Neotropical (in press).

Simond, P. L. 1901. Note sur une coccidie nouvelle, Coccidium kermoganti, parasite de Gabialis gangeticus. Comptes Rendus des Seances, Societe de Biologie 53: 483-485. 